TINJAUAN PUSTAKA

\title{
MALARIA PADA MASA KEHAMILAN
}

\author{
Selfi Renita Rusjdi \\ Bagian Parasitologi Fakultas Kedokteran Universitas Andalas \\ email : selfirenitarusjdi@fk.umamd.ac.id
}

\begin{abstract}
Abstrak
Malaria merupakan penyakit tropis yang disebabkan oleh parasit Plasmodium dan disebarkan melalui gigitan nyamuk. Diperkirakan 219 juta penduduk dunia terinfeksi malaria dan sebanyak 660.000 diantaranya meninggal setiap tahun. Penyakit ini dapat menyerang semua individu tanpa membedakan umur dan jenis kelamin dan tidak terkecuali wanita hamil. Wanita hamil termasuk golongan yang rentan untuk terkena malaria sehubungan dengan penurunan imunitas di masa kehamilan. Malaria pada kehamilan dapat menimbulkan berbagai keadaan patologi pada ibu hamil dan janin yang dikandungnya. Pada ibu hamil, malaria dapat mengakibatkan timbulnya demam, anemia, hipoglikemia, udema paru akut, gagal ginjal bahkan dapat menyebabkan kematian. Pada janin yang dikandung oleh ibu penderita malaria dapat terjadi abortus, lahir mati, persalinan prematur, berat badan lahir rendah, dan kematian janin. Keadaan patologi yang ditimbulkan ini sangat tergantung pada status imunitas, jumlah paritas dan umur ibu hamil.
\end{abstract}

Kata Kunci :malaria, kehamilan, patologi, imunitas

\begin{abstract}
Malaria is one of topical diseases caused by parasite called Plasmodium and transmitted by mosquito bite. In 2010 an estimated 219 million cases of malaria occurred worldwide and 660,000 people died every year. Malaria can occur in most population and it is not depended on age and sex even pregnant women would be suffer from this disease. Pregnant women are particularly vulnerable to malaria as pregnancy reduces a woman's immunity to malaria. It can cause fever, maternal anaemia, hypoglicemia, acute pulmonary udema and even death. For the unborn child, maternal malaria increases the risk of spontaneous abortion, stillbirth, premature delivery and low birth weight, a leading cause of child mortality. The pathology is depended on imunity, number of pariety dan age of pregnant women.
\end{abstract}

key word: malaria, pregnancy, pathology, immunity 


\section{PENDAHULUAN}

Malaria merupakan penyakit tropis yang disebabkan oleh parasit Plasmodium dan disebarkan melalui gigitan nyamuk. Diperkirakan 219 juta penduduk dunia terinfeksi malaria dan sebanyak 661.000 diantaranya meninggal setiap tahun. ${ }^{(1)}$ Penyakit ini dapat menyerang semua individu tanpa membedakan umur dan jenis kelamin dan tidak terkecuali wanita hamil. Wanita hamil termasuk golongan yang rentan untuki terkena malaria. Malaria dapat disebabkan oleh 4 spesies plasmodium, yaitu Plasmodium falciparum, Plasmodium vivax, Plasmodium malariae, dan Plasmodium ovale. Plasmodium falciparum merupakan plasmodium yang terpenting karena penyebarannya luas, dan mempunyai dampak paling berat terhadap morbiditas dan mortalitas ibu dan janinnya. ${ }^{(2-4)}$

Malaria pada kehamilan dapat menimbulkan berbagai keadaan patologi pada ibu hamil seperti demam, anemia, hipoglikemia, udema paru akut, gagal ginjal bahkan dapat menyebabkan kematian. Pada janin menyebabkan abortus, persalinan prematur, berat badan lahir rendah, dan kematian janin. Kelainan yang ditimbulkan ini sangat tergantung pada status imunitas, jumlah paritas dan umur ibu hamil. Di daerah endemisitas tinggi, dimana penduduknya sudah mempunyai imunitas terhadap malaria, jarang terjadi malaria berat dan kematian. Klinis yang ditimbulkan dan derajat parasitemia juga akan lebih berat pada ibu hamil primigravida dan berumur muda. ${ }^{(2,5,6)}$

Keadaan yang mempengaruhi kejadian malaria pada ibu hamil

Kekebalan terhadap malaria lebih banyak ditentukan dari tingkat transmisi malaria tempat wanita hamil tinggal/berasal, yang dibagi menjadi 2 golongan besar yaitu Stable transmission / transmisi stabil, atau endemik dan Unstable transmission / transmisi tidak stabil, epidemik atau non-endemik. Orang-orang yang berada di daerah transmisi stabil akan terusmenerus terpapar malaria karena sering menerima gigitan nyamuk infektif setiap bulannya sehingga imunitas yang terbentuk cukup signifikan untuk bertahan dari serangan parasit malaria. Orang yang berada di daerah Unstable transmission, epidemik atau nonendemik jarang terpapar malaria dan hanya menerima rata-rata kurang dari 1 gigitan nyamuk infektif/tahun. Wanita hamil yang berada di daerah tersebut akan mengalami peningkatan resiko penyakit maternal berat, kematian janin, kelahiran prematur dan kematian perinatal. Ibu hamil yang menderita malaria berat di daerah ini memiliki risiko kemungkinan fatal lebih dari 10 kali dibandingkan ibu tidak hamil yang menderita malaria berat di daerah yang sama. $^{(2,5,7)}$

Wanita hamil lebih rentan terkena malaria dibandingkan dengan wanita yang tidak hamil. Kerentanan ini semakin tinggi pada kehamilan pertama dan kedua. Kerentanan terhadap malaria ini berhubungan erat dengan proses imunologi dan perubahan hormonal di masa kehamilan. ${ }^{(8,9)}$ Konsentrasi eritrosit yang terinfeksi parasit banyak ditemukan di daerah intervillus plasenta. Keadaan ini berhubungan dengan supresi sistim imun baik humoral maupun seluler selama kehamilan sehubungan dengan keberadaan fetus sebagai "benda asing" di dalam tubuh ibu. Supresi sistim imun selama kehamilan terjadi karena perubahan hormonal terutama hormon progesteron dan kortisol. Konsentrasi hormon progesteron yang meningkat selama kehamilan berefek menghambat aktifasi limfosit T terhadap stimulasi antigen. ${ }^{(5)}$ 
Dari penelitian epidemiologi diketahui bahwa Infeksi malaria kronik berhubungan erat dengan gangguan pertumbuhan janin dan anemia pada ibu hamil sedangkan infeksi akut (dengan derajat parasitemia yang tinggi) berhubungan dengan kelahiran prematur. ${ }^{(10,11)}$

\section{Keadaan patologi pada ibu hamil}

a. Demam

Demam akibat malaria pada ibu hamil biasanya terjadi pada primigravida yang belum mempunyai kekebalan terhadap malaria. Pada ibu hamil multigravida dan berasal dari daerah endemisitas tinggi jarang terjadi gejala demam walaupun mempunyai derajat parasitemia yang tinggi. Klinis demam ini sangat berhubungan dengan proses skizogoni (pecahnya merozoit/ skizon) dan terbentuknya sitokin dan atau toksin lainnya. ${ }^{(2,5)}$

b. Anemia

Berdasarkan defenisi WHO, seorang wanita hamil dikatakan anemia apabila kadar hemoglobin $(\mathrm{Hb})$ kurang dari 11 gram/dl. Anemia yang terjadi pada trimester pertama kehamilan sangat berhubungan dengan kejadian Berat Badan Lahir Rendah (BBLR). Hal ini disebabkan karena Pertumbuhan janin terjadi sangat pesat terjadi pada usia kehamilan sebelum 20 minggu. Anemia akibat malaria terjadi karena pecahnya eritrosit yang terinfeksi dan yang tidak terinfeksi. Pecahnya eritrosit yang tidak terinfeksi terjadi akibat meningkatnya fragilitas osmotik sehingga mengakibatkan autohemolisis. Pada malaria falciparum dapat terjadi anemia yang berat karena semua umur eritrosit dapat diserang. ${ }^{(2,5)}$

c. Hipoglikemia

Komplikasi malaria berupa hipoglikemia lebih sering terjadi pada wanita hamil dibandingkan dengan individu yang tidak hamil. Keadaan hipoglikemia ini sering tidak terdeteksi karena gejala hipoglikemia itu sendiri mirip dengan gejala malaria. Gangguan susunan saraf pusat akibat hipoglikemi sering diragukan dengan malaria serebral. Hipoglikemia yang tidak diatasi segera dapat jatuh ke keadaan asidosis laktat yang dapat mengakibatkan fetal distress. ${ }^{(2,11)}$

Hipoglikemia akibat malaria pada wanita hamil terjadi karena beberapa hal antara lain; adanya perubahan metabolisme karbohidrat terutama pada trimester akhir kehamilan, kebutuhan glukosa dari eritrosit yang terinfeksi lebih tinggi dibandingkan dengan eritrosit yang tidak terinfeksi, peningkatan fungsi sel beta pankreas, peningkatan sekresi adrenalin dan disfunsi susunan saraf pusat. ${ }^{(2,11)}$

d. Edema paru akut

Edema paru akut sering terjadi pada trimester kedua dan ketiga. Kondisi ini terjadi karena beberapa sebab yaitu peningkatan permeabilitasvaskuler sekunder terhadap emboli dan Disseminated Intravascular Coagulation (DIC), disfungsi berat mikrosirkulasi, proses alergi, terapi cairan yang berlebihan bersamaan dengan gangguan fungsi kapiler alveoli, malaria serebral, tingkat parasitemi yang 
tinggi, hipotensi, asidosis dan uremia. $^{(11)}$

e. Malaria serebral

Keadaan malaria serebral antara lain disebabkan oleh obstruksi mekanis pembuluh darah otak akibat berkurangnya deformabilitas eritrosit yang terinfeksi parasit dan terjadinya adhesi eritroit yang mengandung parasit di endotel vaskuler yang menimbulkan peningkatan permeabilitas sehingga menimbulkan perubahan sawar darah otak dan udem. ${ }^{(2,5)}$

\section{Keadaan patologi pada janin}

Ibu hamil yang menderita malaria dapat berakibat buruk pada janin yang dikandungnya. Pengaruh pada janin yang paling sering terjadi adalah Berat Badan Lahir Rendah (BBLR). Bayi yang lahir dengan berat badan rendah dapat disebabkan oleh kelahiran prematur dan gangguan pertumbuhan janin. Kondisi ini dapat terjadi akibat malaria di masa kehamilan karena adanya gangguan suplai nutrisi dan oksigen dari ibu ke janin yang dikandungnya. Gangguan sirkulasi uteroplasenta terjadi akibat adanya sekuestrasi eritrosit terinfeksi yang terus mengkonsumsi glukosa dan oksigen eritrosit, terjadinya penebalan membran sitotropoblas dan kondisi anemia pada ibu. Selain itu, proses inflamasi yang diperantarai oleh sitokin Th1 akibat infeksi parasit malaria ini juga mempengaruhi secara langsung proses tumbuh kembang janin. Apabila infeksi yang terjadi cukup berat, malaria di masa kehamilan dapat mengakibatkan abortus atau stillbirth. ${ }^{(6,12)}$

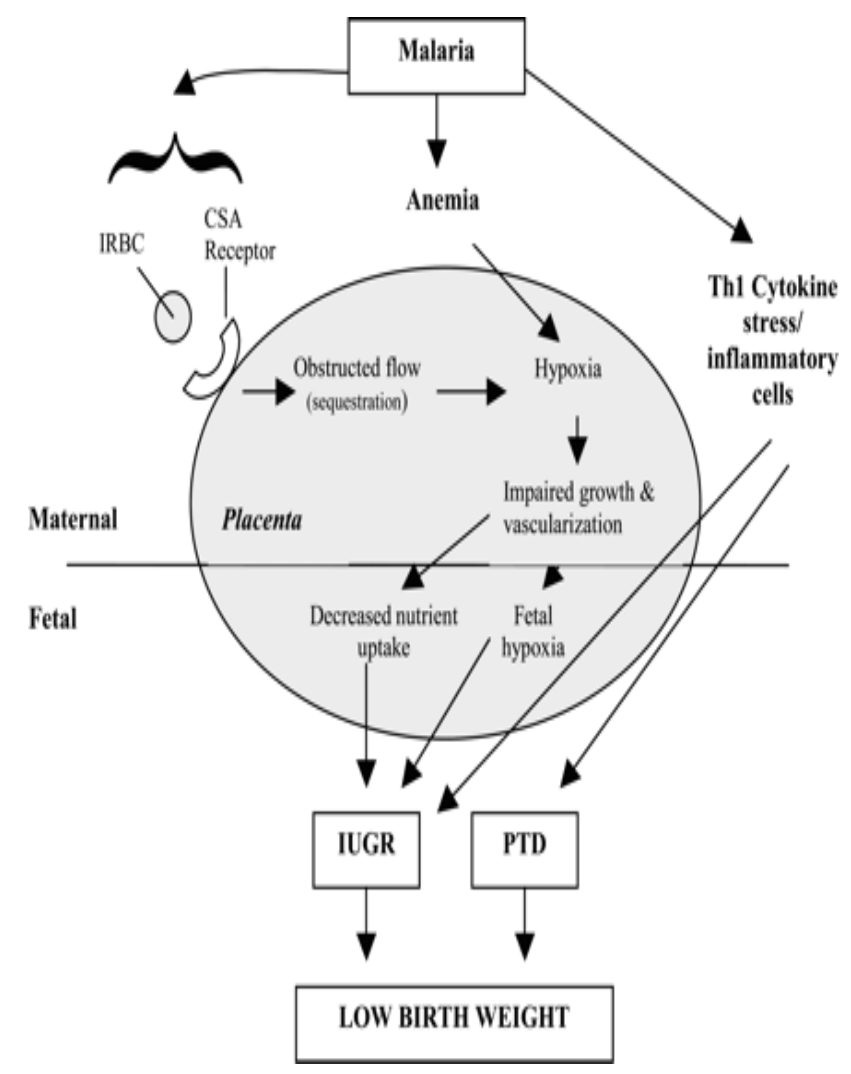

Mekanisme terjadinya kelahiran prematur dan gangguan pertumbuhan janin akibat malaria pada kehamilan.(Rogerson, 2007)

\section{Perubahan Patologis Plasenta}

Pada infeksi P.falciparum terjadi akumulasi eritrosit terinfeksi yang lebih banyak di daerah intervillus plasenta dibandingkan dengan sirkulasi perifer. Eritrosit yang mengandung parasit ini lebih banyak dijumpai pada sisi maternal plasenta dibandingkan dengan sirkulasi fetal. Pada infeksi aktif, plasenta terlihat hitam atau abu-abu dan sinusoid padat dengan eritrosit terinfeksi. Secara histologis ditandai oleh sel eritrosit berparasit dan pigmen malaria dalam ruang intervilli plasenta, monosit mengandung pigmen, infiltrasi mononuklear, simpul sinsitial (syncitial 
knotting), nekrosis fibrinoid, deposit hemozoin hasil penghancuran eritrosit, kerusakan trofoblas, penebalan membrana basalis trofoblas. Keadaan nekrosis sinsitiotrofoblas, kehilangan mikrovilli dan penebalan membrana basalis trofoblas akan menyebabkan aliran darah ke janin berkurang dan akan terjadi gangguan nutrisi pada janin. Lesi bermakna yang ditemukan adalah penebalan membrana basalis trofoblas, pengecilan mikrovilli fokal menahun. Bila villi plasenta dan sinus venosum mengalami kongesti dan terisi eritrosit terinfeksi dan makrofag, maka aliran darah plasenta akan berkurang dan ini dapat menyebabkan abortus, lahir prematur, lahir mati ataupun berat badan lahir rendah. Berbeda dengan P.falciparum, P.vivax tidak mengalami sekuestrasi di plasenta. Keadaan ini mengindikasikan bahwa kejadian berat badan lahir rendah yang diakibatkannya disebabkan oleh perubahan sistemik dan bukan oleh perubahan lokal pada plasenta. ${ }^{(5,6,13)}$

Proses sekuestrasi eritrosit terinfeksi pada plasenta sangat berbeda dengan proses sekuestrasi yang terjadi pada otak atau organ lain yang diperantarai oleh reseptor CD36 and ICAM-1. Proses sekuetrasi pada plasenta terjadi karena adanya molekul adhesi chondroitin sulphate A (CSA) dan hyaluronic acid (HA). Chondroitin sulphate A dan hyaluronic acid ini diekspresikan oleh sinstiotropoblas yang membatasi ruang intervilli plasenta. ${ }^{(6,14)}$

Sekuestrasi terjadi karena adanya ikatan antigen spesifik yang diekspresikan oleh eritrosit terinfeksi dengan molekul adhesi CSA dan HA. Sekuestrasi dapat dicegah oleh antibodi yang dapat menghambat terjadinya ikatan antara eritrosit terinfeksi dengan molekul adhesi tersebut (CSA- binding parasite). Ibu primigravida yang

terpapar dengan CSA-binding parasite untuk pertama kalinya akan mengalami parasitemia yang tinggi pada plasenta dikarenakan belum terbentuknya sistem imun yang efektif. Pada ibu hamil yang mengalami malaria plasenta dengan derajat parasitemia yang tinggi bisa saja tidak mengandung parasit di sirkulasi perifernya. $^{(14)}$

\section{Peranan Protein Parasit terhadap Infeksi Plasenta}

Eritrosit terinfeksi yang berada di plasenta mengekspresikan variant survace antigen (VSA) yang unik, yang memegang peranan dalam proses adhesi di runag intervilli plasenta. Ligand yang berperan penting dalam proses adhesi dan variasi antigen tersebut adalah $P$. falciparum Erythrocyte Membrane Protein-1 (PfEMP1). Protein polimorfik ini dikode oleh famili multi gen yang disebut var. Setiap individu parasit P.falciparum akan mengekpresikan satu gen var dalam satu waktu. Pada saat antibodi terhadap suatu PfEMP1 terbentuk, parasit telah membentuk varian PfEMP1 yang lain, sehingga parasit dapat bertahan dari serangan antibodi tersebut. ${ }^{(12,14)}$

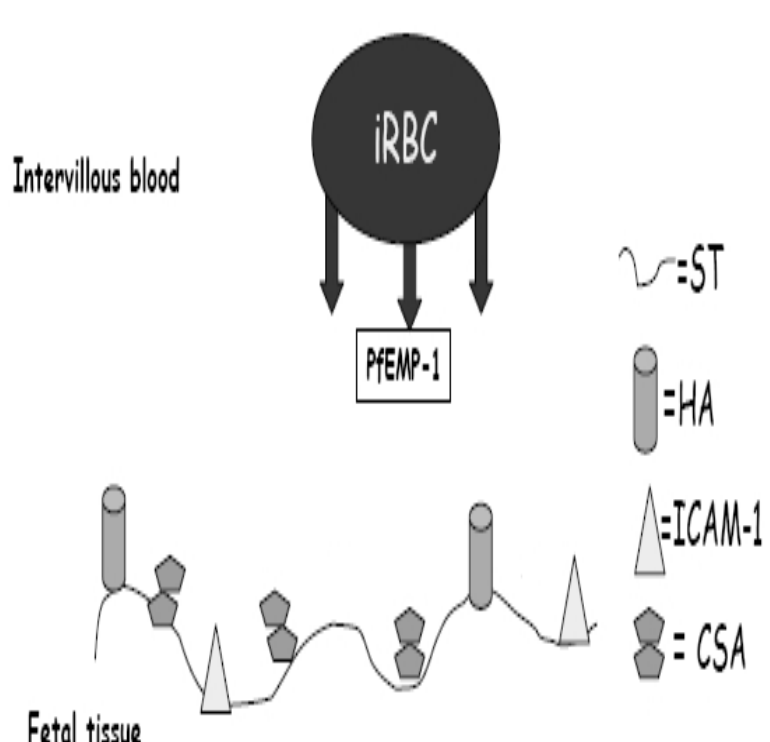

Fetal tissue 
Ikatan eritrosit terinfeksi plasmodium dengan plasenta (Zhang, 2007)

\section{KEPUSTAKAAN}

1. World Health Organization, 2010.

Diunduh dari: http://www.who.int/features/2003/0 4b/en/

2. Cahaya I. Pengaruh malaria selama kehamilan. Universitas Sumatera Utara. USU digital library 2003.

3. Harijanto PN. Gejala Klinik Malaria. Dalam : Harijanto PN, ed. Malaria Epidemiologi, Patogenesis, Manifestasi Klinis dan Penanganan. Jakarta : EGC, cetakan pertama, 2006; 151-65. Menendezab C, Mayor A. Congenital malaria: The least known consequence of malaria in pregnancy. Semin Fetal Neonatal Med June 2007;12(3):207-213Suparman E, Suryawan A. Malaria pada Kehamilan. Jurnal Kesehatan Masyarakat 2004; 4(1) :21-40.

4. Rogerson SJ, Pollina E, Getachew A, Tadesse E, Lema VM, Molyneux ME. Placental monocyte infi ltrates in response to Plasmodium falciparum infection and their association with adverse pregnancy outcomes. Am J Trop Med Hyg 2003; 68: 115-19.

5. Quinn TC. 1992. Parasitic Disease During Pregnancy. Sciarra JJ, Eschenbach DA, Depp R, eds. In: Gynecology and Obstetrics. Volume 3. Philadephia : JB Lippincott Company, 1-6.
6. Raghupathy R. Th1-type immunity is incompatible with successful pregnancy. Immunol Today 1997; 18: $478-82$.

7. Pearson RD. Parasites, pregnancy, prolactin and pandemics? Trends Parasitol 2005; 21: 555-6.

8. Shulman CE, Marshall T, Dorman $\mathrm{EK}$, et al. Malaria in pregnancy: adverse eff ects on haemoglobin levels and birthweight in primigravidae and multigravidae. Trop Med Int Health 2001; 6: 7708.

9. Rogerson SJ, Pollina E, Getachew A, Tadesse E, Lema VM, Molyneux ME. Placental monocyte infi ltrates in response to Plasmodium falciparum infection and their association with adverse pregnancy outcomes. Am J Trop Med Hyg 2003; 68: 115-19.

10. Guyatt LH, Snow WR. Impact of Malaria during Pregnancy on Low Birth Weight in Sub-Saharan Africa. Clinical Microbiology Reviews 2004; 17(4): 760-9.

11. Beeson JG, Amin N, Kanjala M, Rogerson SJ. Selective accumulation of mature asexual stages of Plasmodium falciparuminfected erythrocytes in the placenta. Infect Immun 2002; 70: 5412-5.

12. Mens FP, Bojtor CE, Schallig HDF. Molecular interactions in the placenta during malaria infection. European Journal of Obstetrics \& Gynecology and Reproductive Biology 152 (2010) 126-32. 